\title{
The potential use of DNA methylation biomarkers to identify risk and progression of type 2 diabetes
}

\author{
Linn Gillberg ${ }^{1,2}$ * and Charlotte Ling $^{3}$ \\ 1 Diabetes and Metabolism, Department of Endocrinology, Rigshospitalet, Copenhagen, Denmark \\ 2 Faculty of Health and Medical Sciences, University of Copenhagen, Copenhagen, Denmark \\ ${ }^{3}$ Epigenetics and Diabetes Unit, Department of Clinical Sciences, Lund University Diabetes Centre, Malmö, Sweden
}

\section{Edited by:}

Antonio Brunetti, University "Magna

Græcia" of Catanzaro, Italy

\section{Reviewed by:}

Ghislain Rocheleau, Université Lille 2, France

Tarik Issad, University Paris

Descartes, France

*Correspondence:

Linn Gillberg, Diabetes and Metabolism, Department of

Endocrinology, Rigshospitalet, Tagensvej 20, Section 7652,

Copenhagen, DK-2200, Denmark e-mail: linn.gillberg@rh.regionh.dk
Type 2 diabetes mellitus (T2D) is a slowly progressive disease that can be postponed or even avoided through lifestyle changes. Recent data demonstrate highly significant correlations between DNA methylation and the most important risk factors of T2D, including age and body mass index, in blood and human tissues relevant to insulin resistance and T2D. Also, T2D patients and individuals with increased risk of the disease display differential DNA methylation profiles and plasticity compared to controls. Accordingly, the novel clues to DNA methylation fingerprints in blood and tissues with deteriorated metabolic capacity indicate that blood-borne epigenetic biomarkers of T2D progression might become a reality. This Review will address the most recent associations between DNA methylation and diabetes-related traits in human tissues and blood. The overall focus is on the potential of future epigenome-wide studies, carried out across tissues and populations with correlations to pre-diabetes and T2D risk factors, to build up a library of epigenetic markers of risk and early progression of T2D. These markers may, tentatively in combination with other predictors of T2D development, increase the possibility of individual-based lifestyle prevention of T2D and associated metabolic diseases.

Keywords: biomarkers, DNA methylation, epigenetics, prediction, prevention, type 2 diabetes
The complex multi-organ disease type 2 diabetes mellitus (T2D) is difficult to predict and cure. Abnormalities in glucose metabolism and states of intermediate hyperglycemia are established long before overt T2D develops $(1,2)$. Therefore, prediction of prediabetes and early T2D progression enables individuals at high risk to reduce the likelihood of developing the disease through lifestyle changes (3-5). Epigenetics, which can be described as heritable, cell-specific modifications of the DNA and its associated proteins, which can alter the expression of genes, has been implicated in the pathogenesis of T2D and other complex age-related diseases (6-15). Methylation of cytosine residues in DNA (DNA methylation) is the most studied epigenetic trait, and recent data show significant influences of age and lifestyle related risk factors such as overweight and physical activity on site-specific DNA methylation in blood and tissues relevant for T2D (11, 14, 16-20). This review will discuss the potential of identifying DNA methylation biomarkers to predict development of T2D.

\section{THE HETEROGENEITY OF TYPE 2 DIABETES}

The main risk factors for T2D are age, overweight defined by a high body mass index (BMI), an unhealthy diet, reduced physical activity, an adverse intrauterine environment, and an unfavorable genetic predisposition (4, 5, 21-23). Large-scale studies indicate that the incidence of T2D and pre-diabetes can be reduced through lifestyle changes such as non-smoking, physical activity, improved diet, and weight loss $(3,24)$. Studies suggest insulin resistance in the liver and peripheral tissues (skeletal muscle and adipose tissue) as a predictive marker of future T2D development $(2,25,26)$. Insulin resistance in different tissues together challenges the pancreatic beta cells to produce and secrete increased amounts of insulin. The capacity of insulin production at these challenged states largely determines the likelihood of T2D development. Although several of the identified genetic risk variants of T2D seem to influence insulin processing and secretion (27), the individual capacity of beta cell function during long-term challenged states cannot yet be predicted. Similarly, there is a lack of predictive markers of the individual capability to maintain glucose homeostasis during challenged metabolic conditions such as overweight, which is determined by key metabolic features such as hepatic and peripheral insulin sensitivity, hepatic glucose production, as well as secretion and action of hormones derived from the intestines, adipocytes, and the brain. To optimize the preventive care of T2D, prediction of the disease should be achieved at an early stage. This could potentially be achieved through epigenetic biomarkers that, in combination with measurements of blood metabolites and possibly also identification of genetic variants associated with T2D, may link the heterogenic etiology and pathogenesis of T2D.

\section{AGE ASSOCIATED DNA METHYLATIONS IN BLOOD AND DIABETES-RELATED TISSUES}

In 2005, a study by Fraga et al. revealed that the pattern of DNA methylations and histone modifications in several tissues were more diverse in monozygotic twin pairs who were older, had different lifestyles, and had spent less of their lives together (28). 
This study was among the first to demonstrate that environmental factors and age can have lifelong impacts on the phenotype by altering DNA methylations across multiple human tissues.

The number of studies that demonstrate highly significant correlations between age and site-specific DNA methylation in diverse human populations is rapidly increasing. Convincing data obtained with both site-specific and epigenome-wide approaches has contributed to the identification of specific cytosines in the human genome where either the addition or removal of an electrophilic methyl group is significantly associated with age $(11,18$, 19, 29-37). These studies have advanced the research of human aging, suggesting that epigenetics is involved in the age-related gradual decline of cellular functions that, opposed to chronological age, is referred to as biological age (38). Indeed, two independent but highly overlapping predictive models of aging, characterized by the DNA methylation levels of 71 and 353 genomic CpG sites respectively, have been developed from epigenomic data derived from several human tissues and cell types obtained with Illumina Infinium HumanMethylation450 BeadChips $(34,39)$. These “epigenetic age clocks" may be promising markers of human aging (34, $39,40)$. Knowledge of the individual aging process could increase our understanding of why some individuals develop complex, age related diseases such as Alzheimer's, cancer, cardiovascular disease, and T2D.

Many of the DNA methylations which represent strong agerelated associations in blood are situated in CpG islands of genes important for human metabolism, which are not functional in blood cells but are highly expressed in metabolically active tissues such as adipose tissue, liver, heart, and skeletal muscle (31, 32, 35, $36,41,42)$. Interestingly, CpG methylation of the krüppel-like factor 14 gene (KLF14), which has been genetically linked to T2D and to high-density lipoprotein cholesterol levels in genome-wide association studies (GWAS) $(43,44)$, was identified in two of the studies mentioned above $(34,39)$. Thus, if age-associated DNA methylations in blood reflect DNA methylations in other tissues, these epigenetic modifications might be involved in age-related diseases and pathologies.

Indeed, an increasing amount of studies demonstrate that distinct age-associated DNA methylations in blood are present in other human tissues including skeletal muscle $(45,46)$, kidney (45), and the brain $(33,45)$. Together, these results point toward a general "epigenetic aging clock" across several human tissues (34), and furthermore indicate that age-induced DNA methylations may affect gene transcription and function. Hereby, they may serve as possible indicators of age-associated progression of insulin resistance and T2D.

\section{DNA METHYLATIONS ASSOCIATED WITH LIFESTYLE-RELATED TRAITS IN BLOOD AND DIABETES-RELATED TISSUES}

Recently, Dick et al. reported significant associations between BMI and site-specific DNA methylation of the gene encoding hypoxia inducible factor 3 alpha (HIF3A) in blood from 479 individuals, as well as in adipose tissue from another population of 635 women (16). This study demonstrates that specific DNA methylations in blood that are associated with a lifestyle-related trait can reflect DNA methylations in other tissues. To date, few other studies report significant associations between DNA methylation and BMI or fat distribution in human blood or adipose tissue (4750), and more studies are needed to consolidate these findings and to discover novel descriptive and mechanistic clues to the association between adipose tissue DNA methylation and overweight. In addition, epigenetic markers of pancreatic beta cell function, glucose tolerance, and insulin sensitivity in liver and peripheral tissues are required in the search for epigenetic biomarkers of T2D development.

The DNA methylation levels and plasticity of $\mathrm{CpG}$ sites in the promoter region of the metabolic regulator PPARGC1A have been extensively studied in relation to T2D. PPARGC1A encodes $\mathrm{PGC1} \alpha$, which is a transcriptional co-activator that regulates expression of numerous genes with a key role in mitochondrial function (51). Hitherto, PPARGC1A promoter methylation represents the best example of site-specific DNA methylation alterations in insulin secretory and insulin responsive tissues from T2D patients $(12,52,53)$ and individuals at increased risk of T2D (53-56). Significant correlations between PPARGC1A promoter methylation and insulin sensitivity have been reported in skeletal muscle (57) and liver (58). Moreover, blood DNA methylation at four loci in PPARGC1A predicted adiposity in children up to 14 years (59). Accordingly, besides age and BMI, associations between DNA methylation and key features responsible for hyperglycemia, such as insulin resistance and beta cell dysfunction, could potentially be present in T2D-relevant tissues. If mirrored in blood, these DNA methylations may constitute predictive markers of T2D progression.

\section{EPIGENETIC AND NON-EPIGENETIC BIOMARKERS FOR DIABETES PROGRESSION}

The research field of epigenetic biomarkers for metabolic diseases is still in its infancy. Among the studies reporting potential epigenetic markers of T2D with predictive or diagnostic character, Hidalgo et al. identified a $\mathrm{CpG}$ site in a gene important for cholesterol transport ( $A B C G 1)$ with DNA methylation levels that were significantly associated with fasting insulin and HOMA-IR in CD4 ${ }^{+} \mathrm{T}$ cells from 837 non-diabetic individuals (60). Another study examined epigenome-wide methylations in blood from twins discordant for T2D, that were followed up with replication and omics analyses, and identified DNA methylation alterations in MALT1 (which has a role in the nuclear factor$\kappa \mathrm{B}$ pathway) as well as the G-protein receptor 6 gene (GPR61), that were suggested to reflect T2D progression (61). In addition, effective screening of the blood-borne human epigenome in relation to T2D was conducted by Toperoff et al. who identified DNA hypomethylation of specific sites in young individuals who later developed T2D (62). Also adipose tissue specific CpG sites in numerous genes associated with T2D (PPARG, IRS1, and TCF7L2) were shown to exhibit differential DNA methylation in individuals with T2D compared to healthy controls (13). PPARG encodes a transcription factor with a key role in adipose tissue and IRS1 encodes insulin receptor substrate one which is involved in insulin signaling. Additionally, TCF7L2 encodes a transcription factor involved in the Wnt signaling pathway. However, these markers of T2D or pre-diabetes need to be further replicated in future studies. 
Small non-coding RNAs (e.g., miRNA and lncRNA) are yet another possible source of biomarkers for disease progression $(63,64)$. Recently, Guay et al. reviewed the potential of using the microRNA profile in blood as an estimates of health status and identified differential miRNA profiles in patients with type 1 diabetes (T1D) and T2D as well as distinct miRNAs which appear to be predictive of long-term complications of diabetes (65). Furthermore, another study reported associations between risk of diabetic nephropathy in T1D cases and blood methylation at 19 CpG sites (66).

Importantly, human experiments aiming to identify diverse markers of T2D progression based on genetic (family history, GWAS SNPs), epigenetic (DNA methylation, histone modifications), transcriptomic, metabolomic, and anthropometric measures, and the combination of these, are ongoing (14, 67-70).

\section{CLINICAL UTILITY OF FUTURE EPIGENETIC BIOMARIKERS}

The current enthusiasm for identification and clinical application of epigenetic biomarkers for early pathological states in complex non-communicable diseases is great. Whereas many DNA methylation biomarkers of T2D are awaiting discovery, a diagnostic test for the early detection of colorectal cancer through blood-borne DNA hypermethylation of the SEPT9 promoter is available and used in the clinic today (71). In short, the Septin9 test is simply a detection of DNA methylation levels in the $\mathrm{v} 2$ region of the SEPT9 promoter in blood plasma which is sampled in the clinic and analyzed in the laboratory (71-73). Here, hypermethylation of the SEPT9 promoter is identified in cell-free DNA that has been released into the bloodstream from tumor cells. In the field of $\mathrm{T} 2 \mathrm{D}$, early identification of more subtle epigenetic markers that mirror tissues with deteriorated metabolic function is desirable. Nevertheless, the strong evidence that an increased risk of complex metabolic diseases originate in early life $(21,74,75)$ opens up possibilities of discovering DNA methylation biomarkers that may help to estimate the individual susceptibility of future T2D development (76). To this end, it is noteworthy that we in a recent study identified reduced DNA methylation and increased gene expression of SEPT9 in pancreatic islets of T2D individuals compared with non-diabetic controls, supporting the role of this gene also in T2D (11).

\section{PERSPECTIVES AND FUTURE CHALLENGES}

Novel research in the field of epigenetics opens up new opportunities of identifying biomarkers for risk and progression of complex metabolic diseases such as T2D. Through epigenome-wide as well as site specific DNA methylation characterization, new information about tissue-specific and tissue-general associations between DNA methylation and age or lifestyle related risk factors of T2D are rapidly revealed. Further insight to these associations will ideally improve the variety and quality of existing predictive T2D biomarkers, and thereby increase the possibilities to postpone, or prevent, T2D in individuals at high risk for the disease.

Epigenetic research will also increase our current understanding of epigenetic patterns and plasticity in humans. Interestingly, mechanistic studies of DNA methylation regulation, recently reviewed by Gabriella Ficz (77), reveal tight associations between cellular signaling pathways and DNA methylation. This implies that external, environmental stimuli are involved in the regulation of epigenetic modifications. Besides further understanding of DNA methylation regulation in different human tissues via external signals and age, mechanistic and descriptive epigenetic studies will increase our understanding of how DNA methylation is inherited and determined by genetic variants $(14,29,77-79)$. Recent reports of DNA methylation changes induced by lifestyle-related factors such as exercise and overfeeding $(14,20,80)$ together with the appearing impact of genetic variation on DNA methylation levels $(18,78,79)$ in metabolically active tissues, suggest that specific DNA methylations might be phenotypic mediators of both environmental and genetic effects. Further descriptive as well as mechanistic studies are required to reveal how these hypothetical genome-epigenome-environment interactions might influence human health and disease, and perhaps also help us to find the "missing heritability" of T2D $(10,79)$. In support of functional and disease-related interactions between genetics and tissue-specific epigenetic patterns, the NIH Roadmap Epigenomics Mapping Consortium published some of the most recent human epigenomic data, where they demonstrate epigenomic enrichments in tissues related to a trait which had previously been associated with a genetic variant (81). An additional layer to this complicated network is the memory of fetal development. Since the epigenetic fingerprints were established during fetal life, an adverse intrauterine environment may be memorized as differences in DNA methylation patterns and plasticity in adult individuals and thereby increase their risk of T2D $(23,54,55,82-85)$.

Future challenges include targeted research that will bring us closer to a better understanding of epigenetic features such as the environmentally influenced plasticity of DNA methylation in different tissues, the influence of heritability and genetic variation on DNA methylations, the epigenetic influence on transcriptional regulation, as well as the mechanistic control of specific DNA methylations that are associated with either age- or lifestyle-related phenotypes.

Prevention of T2D through lifestyle changes can be improved through early discovery of T2D progression. Future research on epigenetics and T2D will possibly result in an archive of epigenetic markers that might aid in the individually targeted prevention of $\mathrm{T} 2 \mathrm{D}$ and associated metabolic diseases.

\section{AUTHOR CONTRIBUTIONS}

LG and CL wrote the work and approve its publication.

\section{ACKNOWLEDGMENTS}

The authors wish to thank colleagues in the Diabetes and Metabolism research group at the Department of Endocrinology, Rigshospitalet, Copenhagen, Denmark, as well as colleagues in the Epigenetics and Diabetes research group at the Department of Clinical Sciences, Lund University Diabetes Centre, Malmö, Sweden, for scientific sharing and inspiring discussions. Especially, we would like to thank Professor Allan Vaag, Rigshospitalet, Copenhagen, Denmark.

\section{REFERENCES}

1. Abdul-Ghani MA, Tripathy D, DeFronzo RA. Contributions of beta-cell dysfunction and insulin resistance to the pathogenesis of impaired glucose 
tolerance and impaired fasting glucose. Diabetes Care (2006) 29(5):1130-9. doi: $10.2337 / \mathrm{dc} 05-2179$

2. Perseghin G, Ghosh S, Gerow K, Shulman GI. Metabolic defects in lean nondiabetic offspring of NIDDM parents: a cross-sectional study. Diabetes (1997) 46(6):1001-9. doi:10.2337/diab.46.6.1001

3. Hu FB, Manson JE, Stampfer MJ, Colditz G, Liu S, Solomon CG, et al. Diet, lifestyle, and the risk of type 2 diabetes mellitus in women. N Engl J Med (2001) 345(11):790-7. doi:10.1056/NEJMoa010492

4. Knowler WC, Barrett-Connor E, Fowler SE, Hamman RF, Lachin JM, Walker EA, et al. Reduction in the incidence of type 2 diabetes with lifestyle intervention or metformin. N Engl J Med (2002) 346(6):393-403. doi:10.1056/NEJMoa012512

5. Tuomilehto J, Lindstrom J, Eriksson JG, Valle TT, Hamalainen H, Ilanne-Parikka $\mathrm{P}$, et al. Prevention of type 2 diabetes mellitus by changes in lifestyle among subjects with impaired glucose tolerance. N Engl J Med (2001) 344(18):1343-50. doi:10.1056/NEJM200105033441801

6. Al-Mahdawi S, Virmouni SA, Pook MA. The emerging role of 5hydroxymethylcytosine in neurodegenerative diseases. Front Neurosci (2014) 8:397. doi:10.3389/fnins.2014.00397

7. Barres R, Zierath JR. DNA methylation in metabolic disorders. Am J Clin Nutr (2011) 93(4):897S-900S. doi:10.3945/ajcn.110.001933

8. Dimopoulos K, Gimsing P, Gronbaek K. The role of epigenetics in the biology of multiple myeloma. Blood Cancer J (2014) 4:e207. doi:10.1038/bcj.2014.29

9. Gautrey HE, van Otterdijk SD, Cordell HJ, Mathers JC, Strathdee G. DNA methylation abnormalities at gene promoters are extensive and variable in the elderly and phenocopy cancer cells. FASEB J (2014) 28(7):3261-72. doi:10.1096/fj.13246173

10. Ling C, Groop L. Epigenetics: a molecular link between environmental factors and type 2 diabetes. Diabetes (2009) 58(12):2718-25. doi:10.2337/db09-1003

11. Dayeh T, Volkov P, Salo S, Hall E, Nilsson E, Olsson AH, et al. Genome-wide DNA methylation analysis of human pancreatic islets from type 2 diabetic and non-diabetic donors identifies candidate genes that influence insulin secretion. PLoS Genet (2014) 10(3):e1004160. doi:10.1371/journal.pgen.1004160

12. Ling C, Del GS, Lupi R, Ronn T, Granhall C, Luthman H, et al. Epigenetic regulation of PPARGC1A in human type 2 diabetic islets and effect on insulin secretion. Diabetologia (2008) 51(4):615-22. doi:10.1007/s00125-007-0916-5

13. Nilsson E, Jansson PA, Perfilyev A, Volkov P, Pedersen M, Svensson MK, et al. Altered DNA methylation and differential expression of genes influencing metabolism and inflammation in adipose tissue from subjects with type 2 diabetes. Diabetes (2014) 63(9):2962-76. doi:10.2337/db13-1459

14. Nitert MD, Dayeh T, Volkov P, Elgzyri T, Hall E, Nilsson E, et al. Impact of an exercise intervention on DNA methylation in skeletal muscle from firstdegree relatives of patients with type 2 diabetes. Diabetes (2012) 61(12):3322-32. doi:10.2337/db11-1653

15. Yang BT, Dayeh TA, Kirkpatrick CL, Taneera J, Kumar R, Groop L, et al. Insulin promoter DNA methylation correlates negatively with insulin gene expression and positively with $\mathrm{HbA}(1 \mathrm{c})$ levels in human pancreatic islets. Diabetologia (2011) 54(2):360-7. doi:10.1007/s00125-010-1967-6

16. Dick KJ, Nelson CP, Tsaprouni L, Sandling JK, Aissi D, Wahl S, et al. DNA methylation and body-mass index: a genome-wide analysis. Lancet (2014) 383(9933):1990-8. doi:10.1016/S0140-6736(13)62674-4

17. Franks PW, Ling C. Epigenetics and obesity: the devil is in the details. BMC Med (2010) 8:88. doi:10.1186/1741-7015-8-88

18. Ling C, Poulsen P, Simonsson S, Ronn T, Holmkvist J, Almgren P, et al. Genetic and epigenetic factors are associated with expression of respiratory chain component NDUFB6 in human skeletal muscle. J Clin Invest (2007) 117(11):3427-35. doi:10.1172/JCI30938

19. Ronn T, Poulsen P, Hansson O, Holmkvist J, Almgren P, Nilsson P, et al. Age influences DNA methylation and gene expression of COX7A1 in human skeletal muscle. Diabetologia (2008) 51(7):1159-68. doi:10.1007/s00125-008-1018-8

20. Ronn T, Volkov P, Davegardh C, Dayeh T, Hall E, Olsson AH, et al. A six months exercise intervention influences the genome-wide DNA methylation pattern in human adipose tissue. PLoS Genet (2013) 9(6):e1003572. doi:10.1371/journal. pgen. 1003572

21. Hales CN, Barker DJ. Type 2 (non-insulin-dependent) diabetes mellitus: the thrifty phenotype hypothesis. Diabetologia (1992) 35(7):595-601. doi:10.1007/ BF00400248

22. The International Diabetes Federation (IDF). IDF Diabetes Atlas. 6th ed. (2014). Available from: http://www.diabetesatlas.org/
23. Vaag A, Brons C, Gillberg L, Hansen NS, Hjort L, Arora GP, et al. Genetic, nongenetic and epigenetic risk determinants in developmental programming of type 2 diabetes. Acta Obstet Gynecol Scand (2014) 93(11):1099-108. doi:10. 1111/aogs.12494

24. Laaksonen MA, Knekt P, Rissanen H, Harkanen T, Virtala E, Marniemi J, et al. The relative importance of modifiable potential risk factors of type 2 diabetes: a meta-analysis of two cohorts. Eur J Epidemiol (2010) 25(2):115-24. doi:10.1007/s10654-009-9405-0

25. DeFronzo RA. Pathogenesis of type 2 (non-insulin dependent) diabetes mellitus: a balanced overview. Diabetologia (1992) 35(4):389-97. doi:10.1007/ BF00401208

26. Eriksson J, Franssila-Kallunki A, Ekstrand A, Saloranta C, Widen E, Schalin $\mathrm{C}$, et al. Early metabolic defects in persons at increased risk for non-insulindependent diabetes mellitus. N Engl J Med (1989) 321(6):337-43. doi:10.1056/ NEJM198908103210601

27. Dimas AS, Lagou V, Barker A, Knowles JW, Magi R, Hivert MF, et al. Impact of type 2 diabetes susceptibility variants on quantitative glycemic traits reveals mechanistic heterogeneity. Diabetes (2014) 63(6):2158-71. doi:10.2337/ db13-0949

28. Fraga MF, Ballestar E, Paz MF, Ropero S, Setien F, Ballestar ML, et al. Epigenetic differences arise during the lifetime of monozygotic twins. Proc Natl Acad Sci U $S$ A (2005) 102(30):10604-9. doi:10.1073/pnas.0500398102

29. Bell JT, Tsai PC, Yang TP, Pidsley R, Nisbet J, Glass D, et al. Epigenome-wide scans identify differentially methylated regions for age and age-related phenotypes in a healthy ageing population. PLoS Genet (2012) 8(4):e1002629. doi:10.1371/journal.pgen.1002629

30. Christensen BC, Houseman EA, Marsit CJ, Zheng S, Wrensch MR, Wiemels JL, et al. Aging and environmental exposures alter tissue-specific DNA methylation dependent upon CpG island context. PLoS Genet (2009) 5(8):e1000602. doi:10.1371/journal.pgen.1000602

31. Garagnani P, Bacalini MG, Pirazzini C, Gori D, Giuliani C, Mari D, et al. Methylation of ELOVL2 gene as a new epigenetic marker of age. Aging Cell (2012) 11(6):1132-4. doi:10.1111/acel.12005

32. Heyn H, Li N, Ferreira HJ, Moran S, Pisano DG, Gomez A, et al. Distinct DNA methylomes of newborns and centenarians. Proc Natl Acad Sci U S A (2012) 109(26):10522-7. doi:10.1073/pnas.1120658109

33. Horvath S, Zhang Y, Langfelder P, Kahn RS, Boks MP, van EK, et al. Aging effects on DNA methylation modules in human brain and blood tissue. Genome Biol (2012) 13(10):R97. doi:10.1186/gb-2012-13-10-r97

34. Horvath S. DNA methylation age of human tissues and cell types. Genome Biol (2013) 14(10):R115. doi:10.1186/gb-2013-14-10-r115

35. Johansson A, Enroth S, Gyllensten U. Continuous aging of the human DNA methylome throughout the human lifespan. PLoS One (2013) 8(6):e67378. doi:10.1371/journal.pone.0067378

36. Steegenga WT, Boekschoten MV, Lute C, Hooiveld GJ, de Groot PJ, Morris TJ, et al. Genome-wide age-related changes in DNA methylation and gene expression in human PBMCs. Age (Dordr) (2014) 36(3):9648. doi:10.1007/s11357014-9648-x

37. Teschendorff AE, Menon U, Gentry-Maharaj A, Ramus SJ, Weisenberger DJ, Shen $\mathrm{H}$, et al. Age-dependent DNA methylation of genes that are suppressed in stem cells is a hallmark of cancer. Genome Res (2010) 20(4):440-6. doi:10.1101/ gr.103606.109

38. Levine ME. Modeling the rate of senescence: can estimated biological age predict mortality more accurately than chronological age? J Gerontol A Biol Sci Med Sci (2013) 68(6):667-74. doi:10.1093/gerona/gls233

39. Hannum G, Guinney J, Zhao L, Zhang L, Hughes G, Sadda S, et al. Genomewide methylation profiles reveal quantitative views of human aging rates. Mol Cell (2013) 49(2):359-67. doi:10.1016/j.molcel.2012.10.016

40. Marioni RE, Shah S, McRae AF, Chen BH, Colicino E, Harris SE, et al. DNA methylation age of blood predicts all-cause mortality in later life. Genome Biol (2015) 16(1):25. doi:10.1186/s13059-015-0584-6

41. Leonard AE, Kelder B, Bobik EG, Chuang LT, Lewis CJ, Kopchick JJ, et al. Identification and expression of mammalian long-chain PUFA elongation enzymes. Lipids (2002) 37(8):733-40. doi:10.1007/s11745-002-0955-6

42. Small KS, Hedman AK, Grundberg E, Nica AC, Thorleifsson G, Kong A, et al. Identification of an imprinted master trans regulator at the KLF14 locus related to multiple metabolic phenotypes. Nat Genet (2011) 43(6):561-4. doi:10.1038/ng.833 
43. Voight BF, Scott LJ, Steinthorsdottir V, Morris AP, Dina C, Welch RP, et al. Twelve type 2 diabetes susceptibility loci identified through large-scale association analysis. Nat Genet (2010) 42(7):579-89. doi:10.1038/ng.609

44. Teslovich TM, Musunuru K, Smith AV, Edmondson AC, Stylianou IM, Koseki $\mathrm{M}$, et al. Biological, clinical and population relevance of 95 loci for blood lipids. Nature (2010) 466(7307):707-13. doi:10.1038/nature09270

45. Day K, Waite LL, Thalacker-Mercer A, West A, Bamman MM, Brooks JD, et al. Differential DNA methylation with age displays both common and dynamic features across human tissues that are influenced by CpG landscape. Genome Biol (2013) 14(9):R102. doi:10.1186/gb-2013-14-9-r102

46. Zykovich A, Hubbard A, Flynn JM, Tarnopolsky M, Fraga MF, Kerksick C, et al. Genome-wide DNA methylation changes with age in disease-free human skeletal muscle. Aging Cell (2014) 13(2):360-6. doi:10.1111/acel.12180

47. Wang X, Zhu H, Snieder H, Su S, Munn D, Harshfield G, et al. Obesity related methylation changes in DNA of peripheral blood leukocytes. BMC Med (2010) 8:87. doi:10.1186/1741-7015-8-87

48. Na YK, Hong HS, Lee DH, Lee WK, Kim DS. Effect of body mass index on global DNA methylation in healthy Korean women. Mol Cells (2014) 37(6):467-72. doi:10.14348/molcells.2014.0073

49. Keller M, Kralisch S, Rohde K, Schleinitz D, Dietrich A, Schon MR, et al. Global DNA methylation levels in human adipose tissue are related to fat distribution and glucose homeostasis. Diabetologia (2014) 57(11):2374-83. doi:10.1007/s00125-014-3356-z

50. Agha G, Houseman EA, Kelsey KT, Eaton CB, Buka SL, Loucks EB. Adiposity is associated with DNA methylation profile in adipose tissue. Int J Epidemiol (2014). doi:10.1093/ije/dyu236

51. Ling C, Poulsen P, Carlsson E, Ridderstrale M, Almgren P, Wojtaszewski J, et al. Multiple environmental and genetic factors influence skeletal muscle PGC-1alpha and PGC-1beta gene expression in twins. J Clin Invest (2004) 114(10):1518-26. doi:10.1172/JCI21889

52. Ribel-Madsen R, Fraga MF, Jacobsen S, Bork-Jensen J, Lara E, Calvanese V, et al. Genome-wide analysis of DNA methylation differences in muscle and fat from monozygotic twins discordant for type 2 diabetes. PLoS One (2012) 7(12):e51302. doi:10.1371/journal.pone.0051302

53. Barres R, Osler ME, Yan J, Rune A, Fritz T, Caidahl K, et al. Non-CpG methylation of the PGC-1alpha promoter through DNMT3B controls mitochondrial density. Cell Metab (2009) 10(3):189-98. doi:10.1016/j.cmet.2009.07.011

54. Brons C, Jacobsen S, Nilsson E, Ronn T, Jensen CB, Storgaard H, et al. Deoxyribonucleic acid methylation and gene expression of PPARGC1A in human muscle is influenced by high-fat overfeeding in a birth-weight-dependent manner. J Clin Endocrinol Metab (2010) 95(6):3048-56. doi:10.1210/jc.2009-2413

55. Gillberg L, Jacobsen SC, Ronn T, Brons C, Vaag A. PPARGC1A DNA methylation in subcutaneous adipose tissue in low birth weight subjects - impact of 5days of high-fat overfeeding. Metabolism (2014) 63(2):263-71. doi:10.1016/j.metabol. 2013.10.003

56. Jorgensen SW, Brons C, Bluck L, Hjort L, Faerch K, Thankamony A, et al. Metabolic response to 36 hours of fasting in young men born small vs appropriate for gestational age. Diabetologia (2015) 58(1):178-87. doi:10.1007/s00125-0143406-6

57. Gillberg L, Jacobsen S, Ribel-Madsen R, Gjesing AP, Boesgaard TW, Ling C, et al. Does DNA methylation of PPARGC1A influence insulin action in first degree relatives of patients with type 2 diabetes? PLoS One (2013) 8(3):e58384. doi:10.1371/journal.pone.0058384

58. Sookoian S, Rosselli MS, Gemma C, Burgueno AL, Fernandez GT, Castano GO, et al. Epigenetic regulation of insulin resistance in nonalcoholic fatty liver disease: impact of liver methylation of the peroxisome proliferator-activated receptor gamma coactivator lalpha promoter. Hepatology (2010) 52(6):1992-2000. doi:10.1002/hep.23927

59. Clarke-Harris R, Wilkin TJ, Hosking J, Pinkney J, Jeffery AN, Metcalf BS, et al. PGC1alpha promoter methylation in blood at 5-7 years predicts adiposity from 9 to 14 years (earlybird 50). Diabetes (2014) 63(7):2528-37. doi:10.2337/db13-0671

60. Hidalgo B, Irvin MR, Sha J, Zhi D, Aslibekyan S, Absher D, et al. Epigenomewide association study of fasting measures of glucose, insulin, and HOMA-IR in the genetics of lipid lowering drugs and diet network study. Diabetes (2014) 63(2):801-7. doi:10.2337/db13-1100

61. Yuan W, Xia Y, Bell CG, Yet I, Ferreira T, Ward KJ, et al. An integrated epigenomic analysis for type 2 diabetes susceptibility loci in monozygotic twins. Nat Commun (2014) 5:5719. doi:10.1038/ncomms6719
62. Toperoff G, Aran D, Kark JD, Rosenberg M, Dubnikov T, Nissan B, et al. Genomewide survey reveals predisposing diabetes type 2-related DNA methylation variations in human peripheral blood. Hum Mol Genet (2012) 21(2):371-83. doi: $10.1093 / \mathrm{hmg} / \mathrm{ddr} 472$

63. Esguerra JL, Mollet IG, Salunkhe VA, Wendt A, Eliasson L. Regulation of pancreatic beta cell stimulus-secretion coupling by microRNAs. Genes (Basel) (2014) 5(4):1018-31. doi:10.3390/genes5041018

64. Esguerra JL, Eliasson L. Functional implications of long non-coding RNAs in the pancreatic islets of Langerhans. Front Genet (2014) 5:209. doi:10.3389/fgene. 2014.00209

65. Guay C, Regazzi R. Circulating microRNAs as novel biomarkers for diabetes mellitus. Nat Rev Endocrinol (2013) 9(9):513-21. doi:10.1038/nrendo. 2013.86

66. Bell CG, Teschendorff AE, Rakyan VK, Maxwell AP, Beck S, Savage DA. Genomewide DNA methylation analysis for diabetic nephropathy in type 1 diabetes mellitus. BMC Med Genomics (2010) 3:33. doi:10.1186/1755-8794-3-33

67. Andersen GS, Thybo T, Cederberg H, Oresic M, Esteller M, Zorzano A, et al. The DEXLIFE study methods: identifying novel candidate biomarkers that predict progression to type 2 diabetes in high risk individuals. Diabetes Res Clin Pract (2014) 106(2):383-9. doi:10.1016/j.diabres.2014.07.025

68. Brunetti A, Chiefari E, Foti D. Recent advances in the molecular genetics of type 2 diabetes mellitus. World J Diabetes (2014) 5(2):128-40. doi:10.4239/wjd.v5.i2. 128

69. Lyssenko V, Jorgensen T, Gerwien RW, Hansen T, Rowe MW, McKenna MP, et al. Validation of a multi-marker model for the prediction of incident type 2 diabetes mellitus: combined results of the Inter99 and Botnia studies. Diab Vasc Dis Res (2012) 9(1):59-67. doi:10.1177/1479164111424762

70. Paneni F, Costantino S, Cosentino F. Molecular mechanisms of vascular dysfunction and cardiovascular biomarkers in type 2 diabetes. Cardiovasc Diagn Ther (2014) 4(4):324-32. doi:10.3978/j.issn.2223-3652.2014.08.02

71. Epigenomics AG. Epigenomics - Finding Cancer Early. (2011). Available from: www.epigenomics.com

72. deVos T, Tetzner R, Model F, Weiss G, Schuster M, Distler J, et al. Circulating methylated SEPT9 DNA in plasma is a biomarker for colorectal cancer. Clin Chem (2009) 55(7):1337-46. doi:10.1373/clinchem.2008.115808

73. Model F, Osborn N, Ahlquist D, Gruetzmann R, Molnar B, Sipos F, et al. Identification and validation of colorectal neoplasia-specific methylation markers for accurate classification of disease. Mol Cancer Res (2007) 5(2):153-63. doi:10.1158/1541-7786.MCR-06-0034

74. Ravelli AC, van der Meulen JH, Michels RP, Osmond C, Barker DJ, Hales CN, et al. Glucose tolerance in adults after prenatal exposure to famine. Lancet (1998) 351(9097):173-7. doi:10.1016/S0140-6736(05)79096-6

75. Vaag AA, Grunnet LG, Arora GP, Brons C. The thrifty phenotype hypothesis revisited. Diabetologia (2012) 55(8):2085-8. doi:10.1007/s00125-012-2589-y

76. Mikeska T, Craig JM. DNA methylation biomarkers: cancer and beyond. Genes (Basel) (2014) 5(3):821-64. doi:10.3390/genes5030821

77. Ficz G. New insights into mechanisms that regulate DNA methylation patterning. J Exp Biol (2015) 218(Pt 1):14-20. doi:10.1242/jeb.107961

78. Dayeh TA, Olsson AH, Volkov P, Almgren P, Ronn T, Ling C. Identification of CpG-SNPs associated with type 2 diabetes and differential DNA methylation in human pancreatic islets. Diabetologia (2013) 56(5):1036-46. doi:10.1007/s00125-012-2815-7

79. Olsson AH, Volkov P, Bacos K, Dayeh T, Hall E, Nilsson EA, et al. Genomewide associations between genetic and epigenetic variation influence mRNA expression and insulin secretion in human pancreatic islets. PLoS Genet (2014) 10(11):e1004735. doi:10.1371/journal.pgen.1004735

80. Jacobsen SC, Brons C, Bork-Jensen J, Ribel-Madsen R, Yang B, Lara E, et al. Effects of short-term high-fat overfeeding on genome-wide DNA methylation in the skeletal muscle of healthy young men. Diabetologia (2012) 55(12):3341-9. doi:10.1007/s00125-012-2717-8

81. Kundaje A, Meuleman W, Ernst J, Bilenky M, Yen A, Heravi-Moussavi A, et al. Integrative analysis of 111 reference human epigenomes. Nature (2015) 518(7539):317-30. doi:10.1038/nature14248

82. Heijmans BT, Tobi EW, Stein AD, Putter H, Blauw GJ, Susser ES, et al. Persistent epigenetic differences associated with prenatal exposure to famine in humans. Proc Natl Acad Sci U S A (2008) 105(44):17046-9. doi:10.1073/pnas. 0806560105

83. Jacobsen SC, Gillberg L, Bork-Jensen J, Ribel-Madsen R, Lara E, Calvanese $\mathrm{V}$, et al. Young men with low birthweight exhibit decreased plasticity of 
genome-wide muscle DNA methylation by high-fat overfeeding. Diabetologia (2014) 57(6):1154-8. doi:10.1007/s00125-014-3198-8

84. Ozanne SE, Constancia M. Mechanisms of disease: the developmental origins of disease and the role of the epigenotype. Nat Clin Pract Endocrinol Metab (2007) 3(7):539-46. doi:10.1038/ncpendmet0531

85. Schultz NS, Broholm C, Gillberg L, Mortensen B, Jorgensen SW, Schultz HS, et al. Impaired leptin gene expression and release in cultured preadipocytes isolated from individuals born with low birth weight. Diabetes (2014) 63(1):111-21. doi:10.2337/db13-0621

Conflict of Interest Statement: The authors declare that the research was conducted in the absence of any commercial or financial relationships that could be construed as a potential conflict of interest.
Received: 06 February 2015; accepted: 11 March 2015; published online: 30 March 2015.

Citation: Gillberg L and Ling C (2015) The potential use of DNA methylation biomarkers to identify risk and progression of type 2 diabetes. Front. Endocrinol. 6:43. doi: $10.3389 /$ fendo.2015.00043

This article was submitted to Genomic Endocrinology, a section of the journal Frontiers in Endocrinology.

Copyright (C) 2015 Gillberg and Ling. This is an open-access article distributed under the terms of the Creative Commons Attribution License (CC BY). The use, distribution or reproduction in other forums is permitted, provided the original author (s) or licensor are credited and that the original publication in this journal is cited, in accordance with accepted academic practice. No use, distribution or reproduction is permitted which does not comply with these terms. 